\title{
Clinical experience in the use of inhaled nitric oxide in infants with pulmonary hypertension
}

\author{
ROBERT P LEMKE BMSc MD FRCPC, JAQUES BELIK MD FRCPC, NIELS G GIDDINS MD FRCPC FACC, \\ CARLOS A FAJARDO MD \\ Departments of Neonatology, Winnipeg Children's Hospital, and \\ The Variety Children's Heart Centre, Winnipeg, Manitoba
}

RP LEMKe, J BELIK, NG Giddins, CA FAJARdo. Clinical experience in the use of inhaled nitric oxide in infants with pulmonary hypertension. Can Respir J 1996; 3(5):295-300.

Inhaled nitric oxide (iNO) is a potent local vasodilator. Numerous case reports describe its efficacy in treating persistent pulmonary hypertension of the newborn (PPHN). This report describes experience at the authors' institution with iNO therapy in 10 consecutive infants with PPHN of a number of etiologies. Infants received iNO at doses of 0.2 to $80 \mathrm{ppm}$ for 1 to $481 \mathrm{~h}$. Five infants were classified as responders (20 torr or greater rise in $\mathrm{PaO}_{2}$ ) and one as a partial responder $\left(\mathrm{PaO}_{2}\right.$ rise of 10 to 19 torr $)$. The remaining four did not respond. Overall observed mortality was three of 10, with two of four of nonresponders and the only partial responder dying. Survivors required ventilation for $18 \pm 18$ days and oxygen for $29 \pm 30$ days, and they remained in hospital $40 \pm 30$ days (mean $\pm \mathrm{SD}$ ). Although improvement in oxygenation with iNO was primarily due to reduction in pulmonary pressure, in selective patients, changes in ventilation-perfusion relationships could account for some of the increase in oxygenation. The presence of significant methemoglobinemia in two patients $(7 \%$ and
4.5\%) when the infants' iNO dose was increased to $80 \mathrm{ppm}$ highlights the importance of careful monitoring for toxicity. Further studies are needed to define the best dosage and duration of iNO. While iNO shows great promise in the treatment of PPHN, randomized controlled trials are needed to delineate in which infants iNO use is indicated.

Key Words: Inhaled nitric oxide, Newborn, Persistent pulmonary hypertension

\section{Expérience clinique relative à l'utilisation d'oxyde nitrique en inhalation chez les nour- rissons atteints d'hypertension pulmonaire}

RÉSUMÉ : L'oxyde nitrique en inhalation est un vasodilatateur local puissant. De nombreuses études de cas décrivent son efficacité dans le traitement de l'hypertension pulmonaire persistante du nouveau-né (HPPN). Le présent article décrit l'expérience de l'établissement où pratique l'auteur en ce qui concerne l'utilisation d'oxyde nitrique en inhalation pour traiter une série de 10 nouveau-nés souffrant d'HPPN d'étiologies variées. Les nouveau-nés ont reçu de l'oxyde nitrique en inhalation à des doses de 0,2 à 80 parties/million pendant 1 à 481 heures. Cinq nourris-

voir page suivante

Correspondence and reprints: Dr CA Fajardo, Department of Pediatrics, University of Manitoba, Women's Hospital, 735 Notre Dame Avenue, Winnipeg, Manitoba R3E 0L8. Telephone 204-787-4218, fax 204-787-4973, e-mail cfajardo@cc.umanitoba.ca 
sons ont été classifiés comme « répondants 》 (augmentation de la $\mathrm{PaO}_{2}$ égale ou supérieure à 20 torr) et un nourrisson comme « répondant partiel » (augmentation de la $\mathrm{PaO}_{2}$ de 10 à 19 torr). Les quatre autres nourrissons n'ont pas répondu au traitement. La mortalité globale observée était de trois sur 10 nourrissons, dont deux des quatre nourrissons n'ayant pas répondu au traitement ainsi que le seul nourrisson ayant répondu partiellement. Les survivants ont reçu une ventilation artificielle pendant $18 \pm 18$ jours et de l'oxygène pendant $29 \pm 30$ jours; ils sont restés hospitalisés pendant $40 \pm 30$ jours (moyenne \pm écart-type). Bien qu'une amélioration dans l'oxygénation avec de l'oxyde nitrique en inhalation était principalement attribuable à une réduction de la pression de l'artère pulmonaire, chez certains patients, les changements observés dans le rapport ventilation-perfusion pourraient expliquer une partie de l'augmentation de l'oxygénation. La présence d'une méthémoglobinémie significative chez deux nourrissons ( $7 \%$ et $4,5 \%$ ) quand la dose d'oxyde nitrique en inhalation administrée atteignait 80 parties/million démontre l'importance d'un monitorage rigoureux pour prévenir la toxicité. Il est nécessaire de mener d'autres études pour définir un dosage et une période d'administration optimaux de l'oxyde nitrique en inhalation. Si l'oxyde nitrique en inhalation apparaît comme un traitement prometteur dans l'HPPN, il est indispensable de mener d'autres essais comparatifs randomisés pour préciser chez quels nourrissons l'utilisation de l'oxyde nitrique en inhalation est indiquée.
$\mathrm{N}$ itric oxide is a potent cellular messenger that plays a critical role in the modulation of vascular tone throughout the body (1). An important clinical application of this action is in the treatment of persistent pulmonary hypertension of the newborn (PPHN) (2-9). In this paper we describe all neonates treated at our institution from the time of introduction of nitric oxide as an investigational treatment modality up to the start of our involvement in a large multicentre trial of inhaled nitric oxide (iNO) for PPHN. Our experience thus far raises some interesting points with regard to iNO dosage and treatment duration, measures of response and its potential role in the treatment of many types of neonatal lung disease. Ultimately, the need for multicentre, randomized trials to assess iNO is apparent.

\section{PATIENTS AND METHODS}

Ten infants admitted to the neonatal intensive care unit, Winnipeg Children's Hospital, Winnipeg, Manitoba between September 1993 and March 1994 received iNO. All had clinical evidence of primary or secondary pulmonary hypertension as demonstrated by hypoxemia and a significant difference between pre- and postductal oxygen saturations. All patients were intubated and mechanically ventilated with oxygen requirements in excess of $80 \%$ for at least $8 \mathrm{~h}$ despite

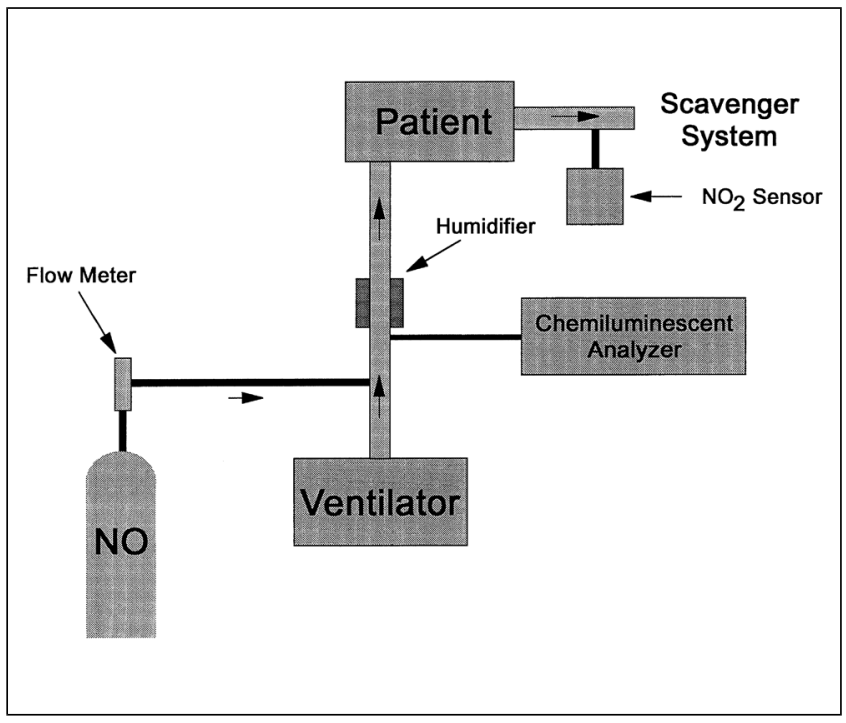

Figure 1) Circuit used to deliver nitric oxide to patients

conventional therapy, consisting of assisted ventilation, bicarbonate administration (to maintain $\mathrm{pH}$ above 7.50), paralysis (pancuronium) and sedation (fentanyl or morphine),

TABLE 1

Patient characteristics, with infants grouped based on response to iNO

\begin{tabular}{|c|c|c|c|c|c|c|c|}
\hline Patient \# & Diagnosis & Birth weight (g) & Gestation (weeks) & Sex & IPPV (days) & Oxygen (days) & Hospital days \\
\hline \multicolumn{8}{|c|}{ Responders } \\
\hline 1 & $\mathrm{CDH}$ & 3300 & 39 & $\mathrm{~F}$ & 57 & 89 & 95 \\
\hline 2 & $\mathrm{CDH}$ & 2700 & 36 & $M$ & 24 & 45 & 53 \\
\hline 3 & Hypoxia & 4000 & 41 & M & 5 & 9 & 20 \\
\hline 4 & $\mathrm{CDH}$ & 3200 & 38 & M & 21 & 28 & 32 \\
\hline 5 & PPHN & 4500 & 39 & M & 3 & 6 & 14 \\
\hline \multicolumn{8}{|c|}{ Partial responder } \\
\hline 6 & RDS & 930 & 27 & M & 9 & 9 & 9 \\
\hline \multicolumn{8}{|c|}{ Nonresponders } \\
\hline 7 & PPHN & 3800 & 41 & $M$ & 7 & 8 & 30 \\
\hline 8 & MAS & 3900 & 41 & $\mathrm{~F}$ & 11 & 15 & 28 \\
\hline 9 & RDS & 1000 & 26 & $M$ & 1 & 1 & 1 \\
\hline 10 & MAS & 3900 & 38 & $M$ & 1 & 1 & 1 \\
\hline
\end{tabular}

CDH Congenital diaphragmatic hernia; iNO Inhaled nitric oxide; IPPV Intermittent positive pressure ventilation; MAS Meconium aspiration syndrome; PPHN Persistent pulmonary hypertension of the newborn; RDS Respiratory distress syndrome 


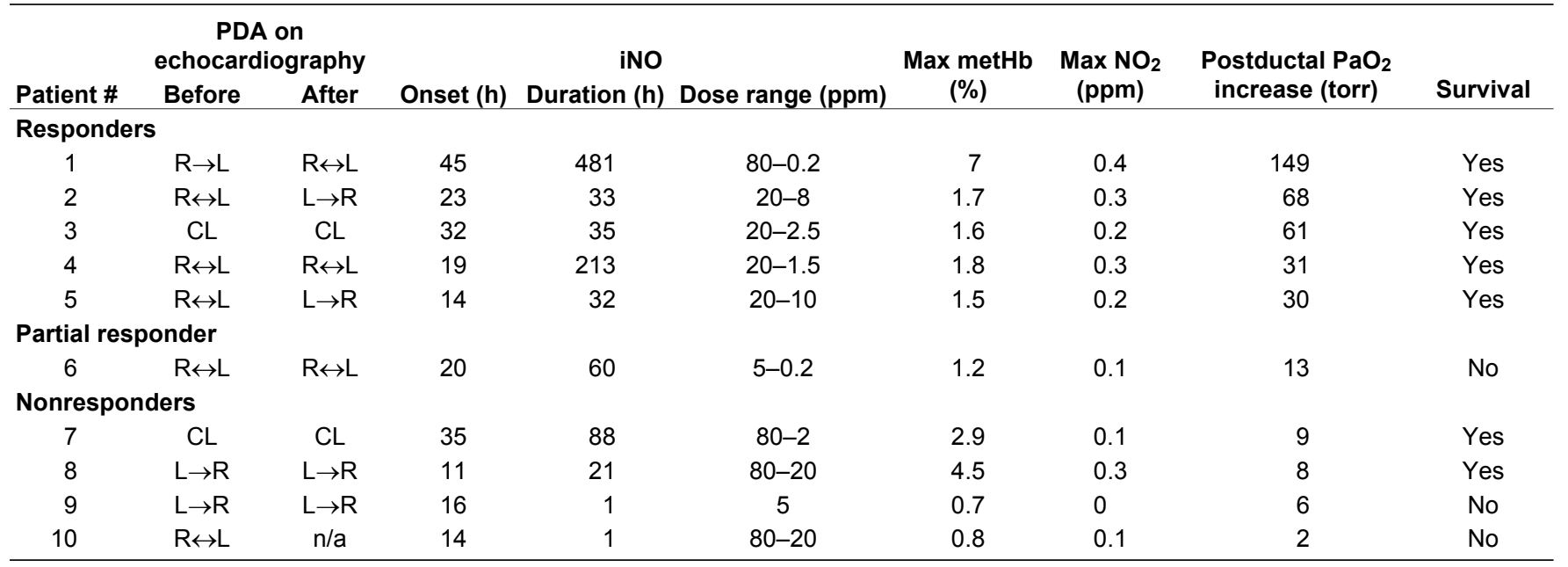

Extrapulmonary shunting via patent ductus arteriosus $(P D A): R \leftrightarrow L$, bidirectional; $L \rightarrow R$, systemic to pulmonary; $R \rightarrow L$, pulmonary to systemic. $C L$ Ductus closed; iNO Inhaled nitric oxide; methb Methemoglobin; n/a Patient died before echocardiography

and inotropic support (dopamine, dobutamine and/or noradrenaline). Surfactant was used at the discretion of the attending neonatologist. One infant with diaphragmatic hernia was treated with high frequency jet ventilation (Bunnell Life Pulse, Bunnell Inc, Utah). Patient characteristics are detailed in Table 1. Patients with nontreatable, life-threatening malformations were excluded.

Infants with any increase in $\mathrm{PaO}_{2}$ were permitted to remain on iNO to allow for possible late response. Patients were weaned from iNO as soon as they were clinically stable. Dose was sequentially reduced as long as ventilator rate, pressures or oxygen concentration did not increase more than $25 \%$ to compensate for any deterioration in oxygenation (ie, saturations below $90 \%$ ).

Infants had postductal arterial lines in place and underwent detailed echocardiographic examinations before starting iNO to assess cardiac performance and confirm normal cardiac anatomy and the presence, magnitude and direction of continuous or intermittent shunting via a patent ductus arteriosus. In addition to serial arterial blood gases, pre- and post ductal oxygen saturations were continually measured to assess the degree of shunting at the level of the ductus as well as the response to iNO. Infants were classified as responders when the $\mathrm{PaO}_{2}$ rose by 20 torr or more and as partial responders if the $\mathrm{PaO}_{2}$ rose 10 to 19 torr whitin half an hour of initiation of iNO. To quantify further the longer term response, the oxygenation index (OI) was also measured. The OI $(\mathrm{OI}=$ [mean airway pressure $x$ fraction of inspired oxygen $x$ $100] / \mathrm{PaO}_{2}$ ) corrects for changes in ventilation over time. For term infants, treatment was initiated at a concentration of 20 ppm for 30 mins, and was increased to $80 \mathrm{ppm}$ for an additional 30 mins if the patient did not experience an improvement in $\mathrm{PaO}_{2}$ of at least 20 torr above baseline on the same ventilator settings and fraction of inspired oxygen, and as long as there were no side effects (eg, hypotension). Premature infants were started on $5 \mathrm{ppm}$ and were not increased fur- ther because of concern of altered platelet function and the potential effect on intraventricular hemorrhage.

The administration of iNO was accomplished by the setup shown in Figure 1. Gas from a tank of nitric oxide (1000 ppm) in balance with nitrogen (Matheson Gas Products Canada) was delivered via a flow meter (\# 603, Matheson Gas Products) into the inspiratory limb of a pressure-limited, time-cycled infant ventilator (100B, Sechrist Industries Inc, California) $60 \mathrm{~cm}$ proximal to the humidifier and $210 \mathrm{~cm}$ proximal to the patient's endotracheal tube connector. The concentration of iNO was measured by a chemiluminescent nitrogen oxides analyzer (Model 8940, Monitor Labs, Lear Siegler Measurement Corp, Colorado) from gas sampled just proximal to the humidifier. Exhaust gases were scavenged from the expiratory limb to prevent environmental contamination.

Potential toxicity from iNO was monitored by regular measurement of blood levels of methemoglobin (metHb) with a co-oximeter (Radiometer, Copenhagen, Denmark) and measures of nitrogen dioxide in expired air by an electrochemical sensor $\left(4584 \mathrm{NO}_{2}\right.$ Analyzer, Exidyne Instrument Technologies, Pennsylvania). Parental informed consent was obtained before administration of $\mathrm{iNO}$, and the protocol was approved by the Human Ethics Committee of The University of Manitoba.

\section{RESULTS}

Patient results are detailed in Table 2. Before the initiation of iNO, patients had a pre- to postductal saturation difference of $34 \pm 14 \%$. Infants received iNO of 0.2 to $80 \mathrm{ppm}$ for between 1 and $481 \mathrm{~h}$. Administration of iNO led to increases in $\mathrm{PaO}_{2}$ of greater than 20 torr in five of 10 patients (responders), an increase of 10 to 19 torr in one patient (partial responder) and a rise of less than 10 torr in four patients (nonresponders) within the first hour of initiating iNO. Responders tended to have a lower initial OI $(23 \pm 17$ versus 

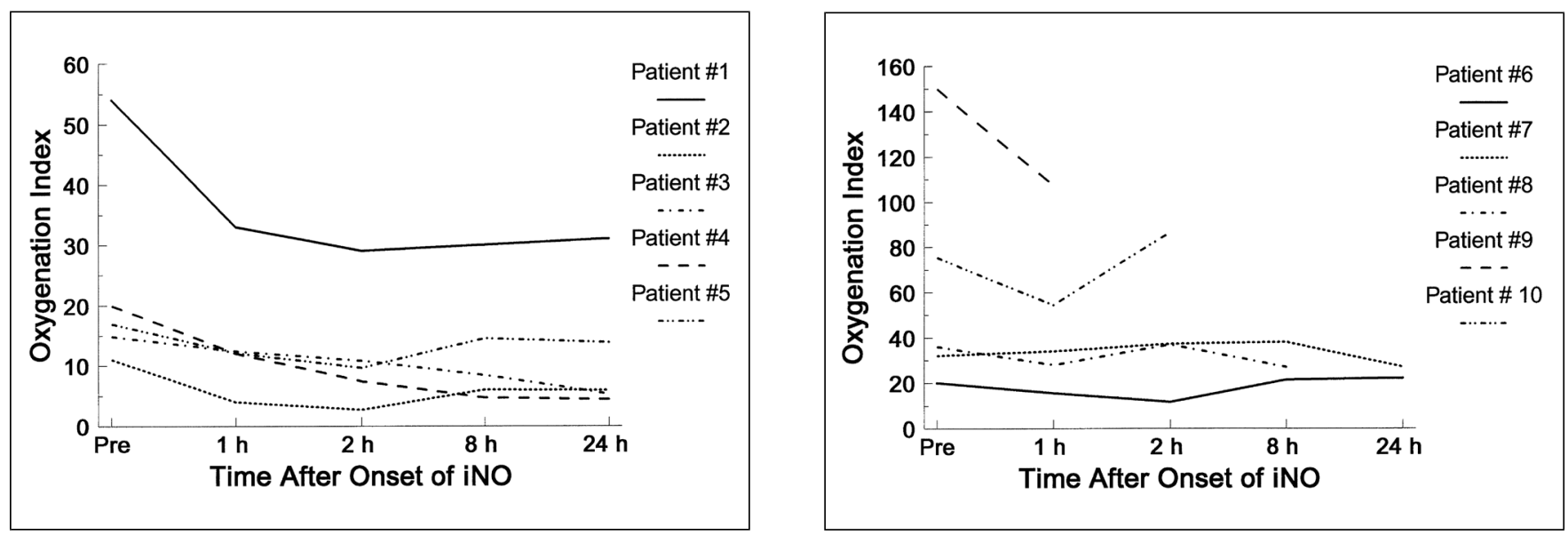

Figure 2) Changes in oxygenation index (OI, defined as mean airway pressure $\times$ fraction of inspired oxygen $\times 100) / \mathrm{PaO} 2)$ for responders (left) and partial and nonresponders (right) during initial $24 \mathrm{~h}$ of inhaled nitric oxide (iNO) administration. Only two responders showed a progressive reduction in OI (Patients \#3 and \#4). Two other responders manifested transient increases in OI between 2 and 8 h after starting iNO (Patients \#2 and \#5). In patients \#9 and \#10, large changes in OIs corresponded to small changes in PaO $\mathrm{O}_{2}$ despite constant ventilator settings

$63 \pm 53)$ and had iNO initiated later in life than partial and nonresponders $(27 \pm 11 \mathrm{~h}$ versus $19 \pm 8 \mathrm{~h}$, mean $\pm \mathrm{SD})$, suggesting that partial and nonresponders had a more severe disease process. Further examination of OI data for the initial 24 $\mathrm{h}$ of iNO revealed two responders who had some deterioration between 2 and $8 \mathrm{~h}$ postonset of iNO (Figure 2). Only two infants, both responders, showed progressive improvement in OIs in the first $24 \mathrm{~h}$.

The maximum concentration of nitrogen dioxide detected in any patient was $0.4 \mathrm{ppm}$. Eight patients had maximum measured metHb below $2.9 \%$. In the remaining two cases, metHb rose to $7 \%$ and $4.5 \%$ when the infants' iNO dose was increased to $80 \mathrm{ppm}$. It rapidly returned to $2.8 \%$ and $2.6 \%$ when their respective doses were reduced to 30 and $20 \mathrm{ppm}$. Only one patient (\#10) suffered deterioration in systemic blood pressure with initiation of iNO. However, this is likely to have been coincidental because this infant was extremely unstable hemodynamically for his entire hospital course until death, soon after iNO was discontinued.

Among the 10 patients, three died, of whom two were nonresponders and one a partial responder. Four patients received surfactant: two with meconium aspiration and two premature infants with respiratory distress syndrome. Survivors required ventilation for $18 \pm 18$ days, oxygen for $29 \pm 30$ days and remained in hospital $40 \pm 30$ days.

\section{DISCUSSION}

Nitric oxide is a potent smooth muscle relaxant produced endogenously in endothelial cells, and because of rapid metabolism exerts its action locally in the pulmonary bed only (1). This selectivity differs greatly from that of other vasodilator agents previously used to treat PPHN (10). To date, published case reports have addressed treatment success in selected patients treated with iNO, while the overall experience of individual centres remains largely unknown (2-9). Although we have treated only a small number of newborns with iNO, our experience thus far raises some interesting points with regard to iNO use in the therapy of PPHN.

Echocardiography has been widely used to assess iNO's effect on ductal shunting, an indicator of the presence and degree of pulmonary hypertension (5). In our 10 patients, neither the direction of ductal shunting on initial echocardiography nor the change in shunting after initiating iNO was correlated with, and therefore predictive of, the degree of improvement in oxygenation. This may be a reflection of the limitations of echocardiography in estimating actual pulmonary artery pressure (11) and its ability to provide only a 'snapshot' of the continually changing relationship between pulmonary and systemic arterial pressures. Conversely, the poor correlation between echocardiographic findings and changes in oxygenation due to iNO may reflect the presence of concomitant altered ventilation-perfusion (V/Q) relationships. Indeed, nitric oxide is known to have important effects on V/Q mismatching $(12,13)$, which can be quantified clinically by comparing the increases in pre- and postductal $\mathrm{PaO}_{2}$ with initiation of iNO. In two of our patients (\#1 and \#4) where both arterial lines were placed, larger improvements in $\mathrm{PaO}_{2}$ were seen preductally (190 and 63 torr) than postductally (149 and 31 torr), indicating that improved V/Q relationships were partially responsible for the response with iNO. Consequently, the response to iNO in any patient must be related to overall clinical improvement in hypoxemia and not just to isolated echocardiographically determined alterations in shunting.

However, the expression of clinical improvement in oxygenation is also susceptible to misinterpretation. Although only five infants were classified as responders due to changes in $\mathrm{PaO}_{2}$, nine of 10 patients showed some improvement in the OI within the $24 \mathrm{~h}$ following iNO administration. Because OI reflects changes in both oxygenation and the patients' ventilator settings, one must be careful in attributing a patient's improvement to iNO alone when examining OI data. Indeed, depending on the 'window' of time one wishes 
to examine, an improvement in the OI while on iNO is seen in all of our patients, despite overall mortality of $30 \%$. The determination of cause and effect is especially difficult in any infant classified as a 'late responder' where improvement may have little to do with iNO. More important, large changes in OI may correspond to clinically insignificant improvements in $\mathrm{PaO}_{2}$ when infants are profoundly hypoxic. For example, although our ninth patient's OI dropped by 43 within $1 \mathrm{~h}$ of institution of iNO (Figure 2), $\mathrm{PaO}_{2}$ increased by only 6 torr. Thus, there is a need for a randomized controlled trial to truly delineate infants who will benefit from iNO.

We note that all three of our congenital diaphragmatic hernia $(\mathrm{CDH})$ patients were successfully treated for their PPHN with iNO, which was administered continuously during their operative repairs, usually a period of instability (14). As a group, infants with $\mathrm{CDH}$ have one of the poorest outcomes in the neonatal extracorporeal membrane oxygenation (ECMO) registry, despite this extremely aggressive form of therapy (15). There is no reliable means of predicting which infants with CDH will survive before treatment is initiated (16-19). We speculate that only infants with $\mathrm{CDH}$ who have lesser degrees of pulmonary hypoplasia will respond to $\mathrm{iNO}$, and that the remainder will continue to require ECMO. Thus, iNO should reduce the overall need for ECMO in $\mathrm{CDH}$ patients.

An important, and largely unanswered, issue is the potential long and short term toxicity of iNO. Nitric oxide reacts with hemoglobin and is then oxidized to metHb (10). Although it normally constitutes less than $3 \%$ of the total hemoglobin present (20), metHb is significantly elevated by increasing doses of iNO, which may produce hypoxia. Similarly, iNO in the presence of oxygen reacts directly to produce higher oxides of nitrogen, which are toxic in high concentrations (21). Because the formation of metHb and higher oxides of nitrogen is dose-dependent, reducing iNO to the lowest possible efficacious levels should reduce potential toxicity (22). Case reports have described using iNO at 2 ppm in children with pulmonary hypertension after cardiac surgery (23) and $0.1 \mathrm{ppm}$ for adults with adult respiratory distress syndrome (ARDS) (24). We observed responses to iNO as low as $0.2 \mathrm{ppm}$ in two of our patients with $\mathrm{CDH}$, which we believe are the lowest doses thus far reported in neonates. Although such doses are small, they are 100 times higher than the concentration of nitric oxide exhaled by healthy humans (25).

In general, the duration of iNO administration has been restricted to less than $72 \mathrm{~h}(2-7)$. Although there is a report of its use at $20 \mathrm{ppm}$ for 23 days, this patient ultimately died while still on iNO (8). Rossaint et al (13) described administration of iNO for 53 days in patients with ARDS. In two of our patients with $\mathrm{CDH}$, iNO was given for nine and 20 days before successful discontinuation. We believe these to be the longest iNO administrations with successful outcome reported in the neonatal literature. The need for prolonged administration of iNO highlights the refractory nature of PPHN and the propensity for continued V/Q mismatching in some patients. Surprisingly, one of our previously mentioned patients with $\mathrm{CDH}$ manifested the largest initial increases in $\mathrm{PaO}_{2}$ of all our patients, suggesting that the magnitude of the initial response is independent of the duration of therapy required.

Although experience in the use of iNO in infants with PPHN is limited, the potential value of iNO in the therapy of this condition is readily apparent. Our small patient number limits our ability to discern which patients will respond to iNO. Indeed, many questions remain concerning the use of iNO, including possible long term toxicity and optimal dosage level and duration of therapy. The ultimate clarification of iNO's future therapeutic role awaits the results of multicentre controlled trials, to which we have now concentrated our efforts.

ACKNOWLEDGEMENTS: Dr Lemke holds a Research Fellowship with the Canadian Lung Association. This work was partially funded by the Children's Hospital of Winnipeg Research Foundation and the Manitoba Medical Services Foundation.

\section{REFERENCES}

1. Zapol WM, Rimar S, Gillis N, Marletta M, Bosken CH. Nitric oxide and the lung. Am J Respir Crit Care Med 1994;149:1375-80.

2. Abman SH, Kinsella JP, Schaffer MS, Wilkening RB. Inhaled nitric oxide in the management of a premature newborn with severe respiratory distress and pulmonary hypertension. Pediatrics 1993;92:606-9.

3. Finer NN, Etches PC, Kamstra B, Tierney AJ, Peliowski A, Ryan CA. Inhaled nitric oxide referred for extracorporeal membrane oxygenation: dose response. J Pediatr 1994;124:302-8.

4. Kinsella JP, Neish SR, Shaffer E, Abman SH. Low dose inhalational nitric oxide in persistent pulmonary hypertension of the newborn. Lancet 1992;340:819-20.

5. Kinsella JP, Neish SR, Ivy DD, Shaffer E, Abman SH. Clinical responses to prolonged treatment of persistent pulmonary hypertension of the newborn with low doses of inhaled nitric oxide. J Pediatr 1993;123:103-8.

6. Kinsella JP, Abman SH. Inhalational nitric oxide therapy for persistent pulmonary hypertension of the newborn. Pediatrics 1993;91:997-8.

7. Lonnqvist PA, Winberg P, Lundell B, Sellden H, Olsson GL. Inhaled nitric oxide in neonates and children with pulmonary hypertension. Acta Paediatr 1994;83:1132-6.

8. Roberts JD, Polaner DM, Lang P, Zapol WM. Inhaled nitric oxide in persistent pulmonary hypertension of the newborn. Lancet 1992;340:818-9.

9. Roberts JD. Inhaled nitric oxide for treatment of pulmonary artery hypertension in the newborn and infant. Crit Care Med 1993;21:S374-5.

10. Roberts JD, Shaul PW. Advances in the treatment of persistent pulmonary hypertension of the newborn. Pediatr Clin North Am 1993;40:983-1004.

11. Sanders SP. Echocardiography. In: Long WA, ed. Fetal and Neonatal Cardiology. Toronto: WB Saunders, 1990:691-701.

12. Kinsella JP, Ivy DD, Abman SH. Inhaled nitric oxide improves gas exchange and lowers pulmonary vascular resistance in severe experimental hyaline membrane disease. Pediatr Res 1994;36:402-8.

13. Rossaint R, Falke KJ, Lopez F, Slama K, Pison U, Zapol WM. Inhaled nitric oxide for the adult respiratory distress syndrome. N Engl J Med 1993;328:399-405.

14. Langer JC, Filler RM, Bohn DJ, et al. Timing of surgery for congenital diaphragmatic hernia: is emergency operation necessary? J Pediatr Surg 1988;23:731-4.

15. Stolar CJH, Snedecor SM, Bartlett BH. Extracorporeal membrane oxygenation and neonatal respiratory failure: experience from the Extracorporeal Life Support Organization. J Pediatr Surg 1991;26:563-71.

16. Bohn D, Tamura M, Perrin D, Barker G, Rabinovitch M. Ventilatory predictors of pulmonary hypoplasia in congenital diaphragmatic hernia, confirmed by morphologic assessment. J Pediatr 1987;111:423-31.

17. Breaux CW, Rouse TM, Cain WS, Georgeson KE. Congenital diaphragmatic hernia in the era of delayed repair after medical and/or extracorporeal membrane oxygenation stabilization: a prognostic and management classification. J Pediatr Surg 1992;27:1192-6. 
18. Wilson JM, Lund DP, Lillehei CW, Vacanti JP. Congenital diaphragmatic hernia: predictors of severity in the ECMO era. J Pediatr Surg 1991;26:1028-34

19. O'Rourke PA. Congenital diaphragmatic hernia: are there reliable predictors? Crit Care Med 1993;21:S380-1.

20. Benz EJ. Hemoglobinopathies with altered solubility or oxygen affinity. In: Wyngaarden JB, Smith LH, Bennett JC, eds. Cecil Textbook of Medicine, 19th edn. New York: WB Saunders, 1992:879-83.

21. Clutton-Brock J. Two cases of poisoning by contamination of nitrous oxide with higher oxides of nitrogen during anesthesia. $\mathrm{Br} J$ Anaesth 1967;39:388-92.

22. Bouchet M, Renaudin M, Raveau C, Mercier J, Dehan M, Zupan V.
Safety requirement for use of inhaled nitric oxide in neonates. Lancet 1993;341:968-9.

23. Miller OI, Celermajer DS, Deanfield JE, Macrae DJ. Very low dose inhaled nitric oxide: a selective pulmonary vasodilator after operations for congenital heart disease. J Thorac Cardiovasc Surg 1994;108:487-94.

24. Gerlach H, Rossaint R, Pappert D, Falkie KJ. Time course and dose response of nitric oxide inhalation for systemic oxygenation and pulmonary hypertension in patients with adult respiratory distress syndrome. Eur J Clin Invest 1993;23:499-502.

25. Gustafsson LE, Leone AM, Persson MG, Wiklund NP, Moncada S. Endogenous nitric oxide in the exhaled air of rabbits, guinea pigs and humans. Biochem Biophys Res Commun 1991;181:852-7. 


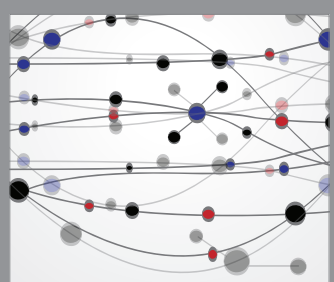

The Scientific World Journal
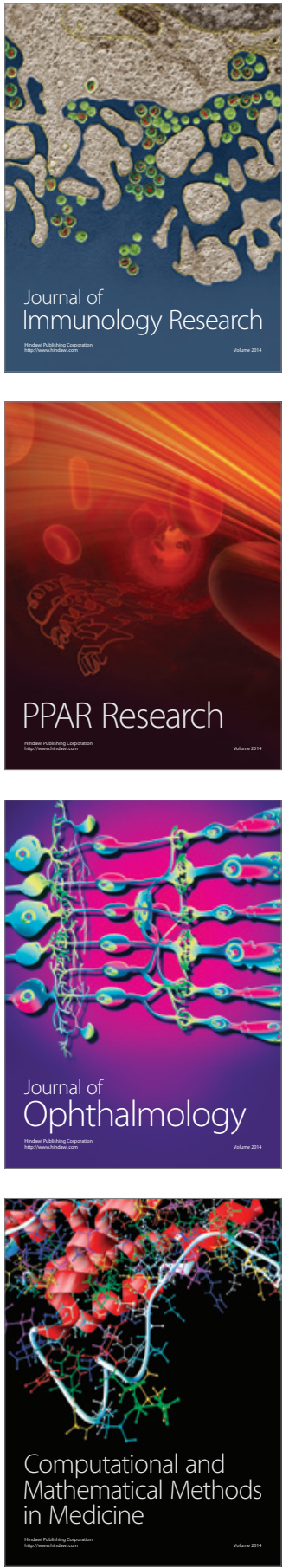

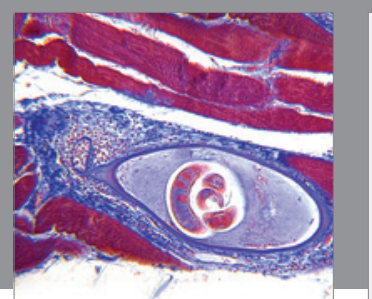

Gastroenterology Research and Practice

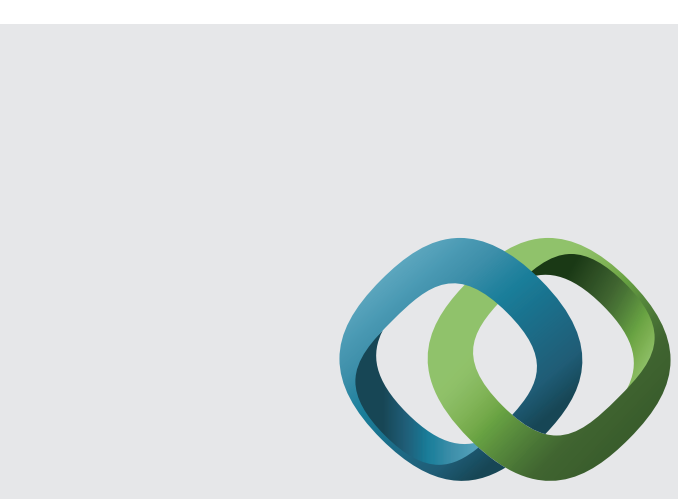

\section{Hindawi}

Submit your manuscripts at

http://www.hindawi.com
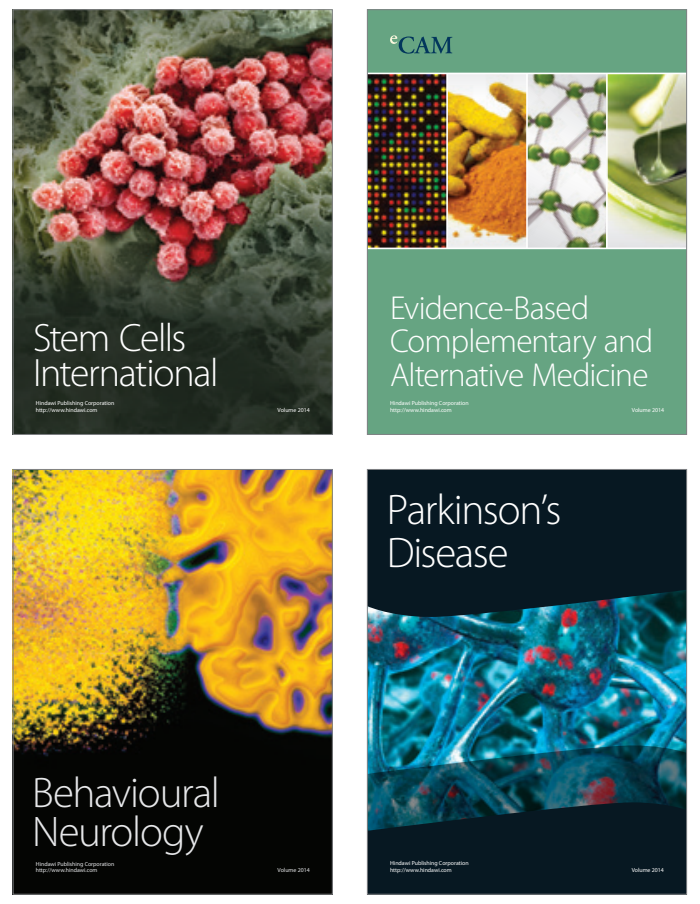
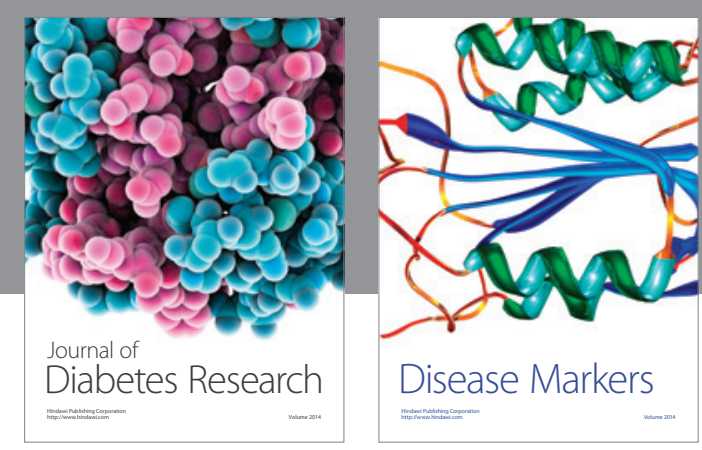

Disease Markers
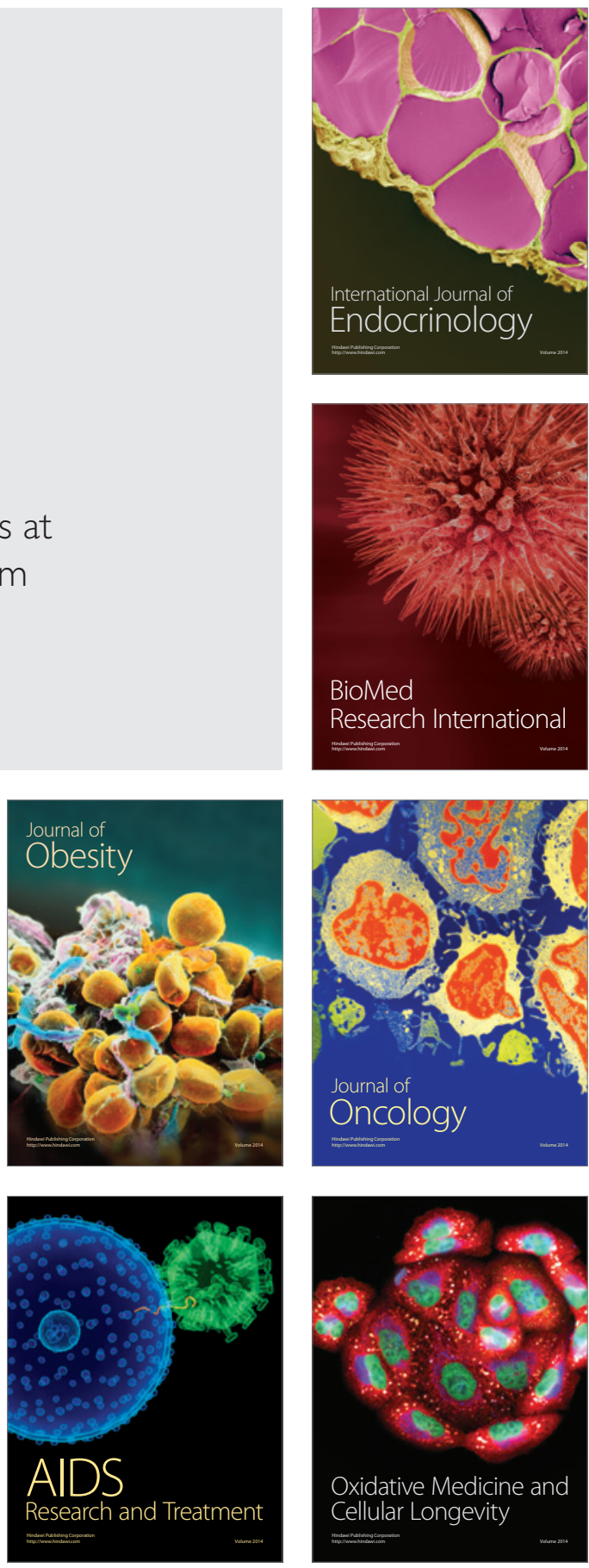